\title{
Changes during vaso-occlusive crisis (VOC) and normal state in sickle cell disease patients
}

\author{
Kenechukwu C Onyekwelu" ${ }^{1 *}$, Silas A Ufelle ${ }^{2}$, Joy E Ikekpeazu ${ }^{1}$, Richard C Ezeh ${ }^{3}$, Chukwuemelie Z Uche ${ }^{1}$ and Iniebong Philip Udoh ${ }^{2}$ \\ ${ }^{1}$ Department of Medical Biochemistry, College of Medicine, University of Nigeria Enugu Campus, Nigeria \\ ${ }^{2}$ Department of Medical Laboratory Sciences, College of Medicine, University of Nigeria Enugu Campus, Nigeria \\ ${ }^{3}$ Department of Medical Biochemistry, ESUT College of Medicine, Parklane, Enugu State Nigeria
}

\begin{abstract}
Background/Aim: Painful vaso-occlusive crisis (VOC) is the most frequent complication of sickle cell disease. The cause of VOC is believed to be ischemic tissue injury from the obstruction of blood flow by sickled erythrocytes. Sickling process leads to hypoxia and acidosis; a cycle that eventually leads to ischemic tissue injury. The study was aimed at evaluating the biochemical and haematological changes in sickle cell disease patients during crisis and steady state.
\end{abstract}

Materials and Methods: One hundred sickle cell anaemia patients attending sickle cell clinic at the University of Nigeria Teaching Hospital, Ituku-Ozalla, Enugu, comprising of 40 males and 60 females, aged 10 - 30 years and 50 (25 males and 25 females) apparently healthy control subjects participated in the study. Blood sample $(5.0 \mathrm{ml})$ was drawn from a peripheral vein during crisis and steady states for biochemical and haematological analysis using haematological auto analyzer and standard spectrophotometric method.

Results: The mean albumin, globulin and total protein concentrations in VOC were significantly higher $(\mathrm{p}<0.05)$ than the mean steady state and the controls. The mean haemoglobin, haematocrit, platelet and red blood cell concentration both in VOC and steady state were significantly lower ( $\mathrm{p}<0.05$ ) than the controls while the total white blood cell concentration $\left(8.5 \pm 1.5 \times 10^{9} / \mathrm{L}\right)$ was significantly higher $(\mathrm{p}<0.05)$ than the mean steady state $\left(7.6 \pm 0.8 \times 10^{9} / \mathrm{L}\right)$ and the controls $(5.1 \pm$ $\left.1.2 \times 10^{9} / \mathrm{L}\right)$

Conclusion: These findings have demonstrated alteration of some biochemical and haematological parameters during VOC and normal state in sickle cell disease.

\section{Introduction}

Sickle cell disease is characterized by painful vaso- occlusive crises, chronic inflammation, recurrent infections and organ damage resulting in a highly reduced quality of life in both adult and children [1-3]. Vaso-occlusive crises caused by sickled red blood cells are responsible for chronic and acute damage to tissue and organs and cause recurrent and unpredictable episodes of acute pain in the affected parts of the body, most usually the arms, legs, joints, and back. There are four phases of vaso-occlusive crisis with the typical painful episode lasting an average of 10 days [4]. The phase 1 which is the prodromal or precrisis phase is associated with numbness and paresthesias which may be related to a decrease in red blood cell deformability and an increase in red blood cell density as more red blood cells clog vascular channels. Phase 2 is often associated with decrease in hemoglobin, an increase in the percentage of dense red blood cells, increased red blood cell distribution width and increased hemoglobin concentration distribution width. In phase 3 , the biochemical and heamatological changes includes anemia, reticulocytosis, leucocytosis, an increase in acute-phase reactants like C-reactive protein and fibrinogen, lactate dehydrogenase which is an indication of tissue damage/bone marrow infarct, creatine phosphokinase indicating skeletal muscle damage. Phase 4 is associated with thrombocytosis, increased fibrinogen levels, and a return to baseline hemoglobin levels with decreased sickle cells [5]. Factors involved in the development of painful crisis arising from vaso -occlusion in sickle cell disease is complex which is triggered by many factors that includes poor deformability of red blood cells, adhesion among multiple cell types and blood components, as well as the local microenvironment like low oxygen concentration and acidosis [6-7]. Sickle red blood cells experience intracellular sickle hemoglobin polymerization under conditions of low oxygen partial pressure, thereby reducing cell deformability [8]. Such reductions in deformability can severely impact blood flow in narrow vessels, ultimately causing a transient or persistent blockage [9]. Competition between the delay time for hemoglobin $S$ polymerization and the red blood cell transit time in microcirculation is likely a key determinant of disease severity [10].

Leukocytes and neutrophils are important players in the pathogenesis of VOC. In sickle mice models generated to study vasoocclusion, leukocytes, and especially neutrophils, were identified as important players in the pathogenesis of VOC $[11,12]$. Leukocytes play an important role in the development of microvascular obstruction and sickle cell disease-related complications [13]. Studies have shown that leukocytosis is associated with severity of sickle cell disease and is a risk factor for major sickle cell-related complications such as stroke, acute chest syndrome and early death [14-16]. Polymorphonuclear

${ }^{\star}$ Correspondence to: Silas A Ufelle. Department of Medical Laboratory Sciences, College of Medicine, University of Nigeria Enugu Campus, Nigeria, E-mail: silas.ufelle@unn.edu.ng

Key words: vaso-occlusive crisis, sickle cell disease, albumin, globulin, platelet

Received: November 08, 2018; Accepted: January 08, 2019; Published: January 11,2019 
neutrophils play an important role in the pathogenesis of vasoocclusive painful sickle cell crisis. Upon activation, polymorphonuclear neutrophils can form neutrophil extracellular traps which consist of a meshwork of extracellular DNA, nucleosomes, histones and neutrophil proteases and neutrophil extracellular traps have been demonstrated to be toxic to endothelial and parenchymal cells [17-19]. Neutrophils play a pivotal role in initiating VOC and their importance has been highlighted in various laboratory and clinical studies [20-22]. In a mouse model of VOC, instead of attaching to endothelium, sickle erythrocytes more commonly adhered to activated neutrophils [20]. Neutrophils from sickle cell disease patients express higher levels of activation molecules that mediate their adherence to endothelium and these immobilized neutrophils may act as cynosure for sickle erythrocytes to attach to and cause VOC [23].

\section{Materials and methods}

\section{Patients and blood collection}

The subjects comprise of 100 sickle cell anemia patients attending clinic at University of Nigeria Teaching hospital, Ituku Ozalla, Enugu Nigeria of both sexes aged 10 to 30 years and 50 apparently healthy age and gender-matched controls. Haemoglobin electrophoresis on cellulose acetate was used to diagnose the homozygous disease [24].

\section{Inclusion and exclusion criteria}

Inclusion criteria: Known patients with sickle cell anaemia as diagnosed by cellulose acetate electrophoresis [24] in steady state and a state of well-being without any symptoms or signs suggestive of crisis established by a careful history and complete physical examination.

Known patients with sickle cell anaemia as diagnosed by cellulose acetate electrophoresis [24] considered clinically to be in VOC based on the following criteria: Bone and joint pains or multiple sites of pain, requirement for analgesics and patients considering the episode as typical of crisis which necessitates hospital admission.

Exclusion criteria: The exclusion criteria were established as follows: patient with disorders that may affect the haematological and biochemical values such as renal and liver disease, pregnancy and any patient with recent blood transfusion during the preceding three months.

\section{Blood collection and analysis}

Blood sample $(6 \mathrm{ml})$ was collected from subjects and controls into tri-potassium ethylene diamine tetra acetic acid anticoagulant containers and plain bottles and analyzed using haematological auto analyzer (Sysmex KX-21N) following manufacturers guideline. Total serum protein, albumin and globulin were further determined on both subjects and controls using standard methods.

\section{Analysis of data}

The Statistical Package for Social Science (SPSS) computer software version 17 was used for data analysis. The results of the tests were analyzed using analysis of variance (ANOVA) and student's t-test at $95 \%$ confidence interval with $p$ value of $\leq 0.05$ been considered as significant.

\section{Ethical Permit}

Ethical permit was sought and obtained from the research and ethics committee of College of Medicine, University of Nigeria, Enugu Campus. The procedures followed in this study were in accordance with the ethical standards of ethics committee on human experimentation.

\section{Results}

The mean albumin, globulin and total protein values in VOC were significantly higher $(\mathrm{p}<0.05)$ than the mean steady state and the controls values (Table 1). The mean haemoglobin, haematocrit, platelet and red blood cell values both in VOC and steady state were significantly lower than the controls values while the total white blood cell value $(8.5 \pm 1.5)$ was significantly higher than the mean steady state $(7.6 \pm 0.8)$ and the control $(5.1 \pm 1.2)$ (Table 2).

Tables 3 and 4 is the mean \pm SD of Biochemical indices of male and female patients during crisis and steady state and its comparison with male and female controls respectively. There was no significant difference between the mean \pm SD of serum albumin, globulin and total protein of sickle cell male and female patients during crisis and steady state when compared with male and female control respectively.

The hematological indices of male during crisis and steady state showed that the mean haemoglobin $(7.8 \pm 0.6)$, haematocrit $(21 \pm 0.5)$ and red blood cell $(3.2 \pm 0.35)$ in VOC were significantly lower than the mean steady state and the controls while the total white blood cell concentration in VOC was significantly higher compared to the mean steady state and the control. The mean platelet in VOC $(85 \pm 10)$ and the steady state $(105 \pm 15)$ were significantly lower when compared with the control (Table 5). The hematological indices of female during crisis and steady state reveled that haemoglobin $(6.5 \pm 0.5)$,

Table 1. The mean \pm SD of Biochemical indices during crisis and steady state

\begin{tabular}{|l|l|l|l|}
\hline Biochemical indices & Crisis stage & Steady stage & Control \\
\hline Albumin $(\mathrm{g} / \mathrm{dl})$ & $5.5 \pm 0.7^{*}$ & $5.1 \pm 0.6$ & $4.8 \pm 0.4$ \\
\hline Globulin $(\mathrm{g} / \mathrm{dl})$ & $4.4 \pm 0.7^{*}$ & $3.4 \pm 0.5$ & $3.1 \pm 0.5$ \\
\hline Total protein $(\mathrm{g} / \mathrm{dl})$ & $9.9 \pm 1.2^{*}$ & $8.5 \pm 1$ & $7.9 \pm 0.9$ \\
\hline${ }^{*}(\mathrm{p}<0.05)$ & & \\
\hline
\end{tabular}

Table 2. The mean \pm SD of haematological indices during crisis and steady state

\begin{tabular}{|c|c|c|c|}
\hline $\begin{array}{l}\text { Haematological } \\
\text { indices }\end{array}$ & Crisis stage & Steady state & Control \\
\hline $\mathrm{HGB}(\mathrm{g} / \mathrm{dl})$ & $7.6 \pm 0.5^{*}$ & $10.3 \pm 1.3^{*}$ & $13.1 \pm 1$ \\
\hline $\operatorname{HCT}(\mathrm{L} / \mathrm{L})$ & $22 \pm 0.8^{*}$ & $30 \pm 1.5^{*}$ & $38 \pm 1.2$ \\
\hline $\mathrm{RBC}\left(\mathrm{x} 10^{12} / \mathrm{L}\right)$ & $3.2 \pm 0.24^{*}$ & $3.6 \pm 0.33^{*}$ & $4.9 \pm 0.27$ \\
\hline $\mathrm{MCV}(\mathrm{FL})$ & $67.86 \pm 0.42$ & $80.23 \pm 0.35$ & $76.71 \pm 0.38$ \\
\hline $\mathrm{MCH}(\mathrm{Pg})$ & $23.63 \pm 0.76$ & $28.56 \pm 0.44$ & $26.79 \pm 0.61$ \\
\hline $\mathrm{MCHC}(\mathrm{g} / \mathrm{dl})$ & $34.98 \pm 0.23$ & $34.87 \pm 0.52$ & $34.93 \pm 0.35$ \\
\hline TWBC (x 109/L) & $8.5 \pm 1.5^{*}$ & $7.6 \pm 0.8$ & $5.1 \pm 1.2$ \\
\hline Platelet (x 109/L) & $98 \pm 12^{*}$ & $118 \pm 10^{*}$ & $158 \pm 10$ \\
\hline \multicolumn{4}{|c|}{$\begin{array}{l}\text { "(p<0.05) } \\
\text { HGB: Haemoglobin; HCT: Hematocrit; RBC: Red blood cell; MCV: Mean corpuscular } \\
\text { volume; MCH: Mean corpuscular hemoglobin; MCHC: Mean corpuscular hemoglobin } \\
\text { concentration; TWBC: Total white blood cell. }\end{array}$} \\
\hline \multicolumn{4}{|c|}{ Table 3. The mean $\pm \mathrm{SD}$ of Biochemical indices of male during crisis and steady state } \\
\hline Biochemical indices & Crisis stage & Steady stage & Control \\
\hline Albumin (g/dl) & $5.2 \pm 0.7^{*}$ & $4.9 \pm 0.64$ & $4.4 \pm 0.5$ \\
\hline Globulin (g/dl) & $4.4 \pm 0.8^{*}$ & $3.2 \pm 0.71$ & $3.1 \pm 0.6$ \\
\hline Total protein $(\mathrm{g} / \mathrm{dl})$ & $9.6 \pm 1.3^{*}$ & $8.1 \pm 0.6$ & $7.5 \pm 0.9$ \\
\hline \multicolumn{4}{|l|}{${ }^{*}(\mathrm{p}<0.05)$} \\
\hline
\end{tabular}

Table 4. The mean \pm SD of Biochemical indices of female during crisis and steady state

\begin{tabular}{|l|l|l|l|}
\hline Biochemical indices & Crisis stage & Steady stage & Control \\
\hline Albumin $(\mathrm{g} / \mathrm{dl})$ & $5.4 \pm 0.6^{*}$ & $5.1 \pm 0.4$ & $5.0 \pm 0.2$ \\
\hline Globulin $(\mathrm{g} / \mathrm{dl})$ & $4.4 \pm 0.5^{*}$ & $3.3 \pm 0.7$ & $3.1 \pm 0.3$ \\
\hline Total protein $(\mathrm{g} / \mathrm{dl})$ & $9.8 \pm 1.1^{*}$ & $8.4 \pm 1.1$ & $8.1 \pm 0.9$ \\
\hline "(p $<0.05)$ & & \\
\hline
\end{tabular}


Table 5. The mean \pm SD of Hematological indices of male during crisis and steady state

\begin{tabular}{|l|l|l|l|}
\hline $\begin{array}{l}\text { Haematological } \\
\text { indices }\end{array}$ & Crisis stage & Steady state & Control \\
\hline $\mathrm{Hb}(\mathrm{g} / \mathrm{dl})$ & $7.8 \pm 0.6^{*}$ & $10.2 \pm 1.5$ & $12.5 \pm 0.5$ \\
\hline $\mathrm{Hct}(\mathrm{L} / \mathrm{L})$ & $21 \pm 0.5^{*}$ & $30 \pm 1.2$ & $36 \pm 0.7$ \\
\hline $\mathrm{RBC}\left(\mathrm{x} \mathrm{10} 0^{12} / \mathrm{L}\right)$ & $3.2 \pm 0.35^{*}$ & $3.5 \pm 0.43$ & $4.6 \pm 0.23$ \\
\hline $\mathrm{MCV}(\mathrm{FL})$ & $65.63 \pm 0.22$ & $85.71 \pm 0.38$ & $78.26 \pm 0.62$ \\
\hline $\mathrm{MCH}(\mathrm{Pg})$ & $24.36 \pm 0.41$ & $29.14 \pm 0.56$ & $27.17 \pm 0.23$ \\
\hline MCHC $(\mathrm{g} / \mathrm{dl})$ & $37.14 \pm 0.13$ & $34 \pm 0.11$ & $34.72 \pm 0.57$ \\
\hline TWBC $(\mathrm{x} \mathrm{10} / \mathrm{L})$ & $7.6 \pm 2^{*}$ & $6.5 \pm 1.5^{*}$ & $4.5 \pm 1$ \\
\hline Platelet $(\mathrm{x} \mathrm{10} / \mathrm{L})$ & $85 \pm 10^{*}$ & $105 \pm 15^{*}$ & $155 \pm 12$ \\
\hline$(\mathrm{p}<0.05)$ & & & \\
\hline
\end{tabular}

* $(\mathrm{p}<0.05)$

HGB: Hemoglobin; HCT: Hematocrit; RBC: Red blood cell; MCV: Mean corpuscular volume; MCH: Mean corpuscular haemoglobin; MCHC: Mean corpuscular hemoglobin concentration; TWBC: Total white blood cell.

Table 6. The mean \pm SD of Hematological indices of female during crisis and steady state

\begin{tabular}{|c|c|c|c|}
\hline $\begin{array}{l}\text { Haematological } \\
\text { indices }\end{array}$ & Crisis stage & Steady state & Control \\
\hline $\mathrm{Hb}(\mathrm{g} / \mathrm{dl})$ & $6.5 \pm 0.5^{*}$ & $10.2 \pm 0.3$ & $12.5 \pm 1$ \\
\hline Hct (L/L) & $18 \pm 0.7^{*}$ & $27 \pm 1$ & $36 \pm 0.6$ \\
\hline $\mathrm{RBC}\left(\mathrm{x} 10^{12} / \mathrm{L}\right)$ & $3.1 \pm 0.8^{*}$ & $3.4 \pm 0.5$ & $4.5 \pm 0.2$ \\
\hline $\mathrm{MCV}(\mathrm{FL})$ & $58.06 \pm 0.23^{*}$ & $79.41 \pm 0.11$ & $80 \pm 0.98$ \\
\hline $\mathrm{MCH}(\mathrm{Pg})$ & $20.97 \pm 0.44^{*}$ & $28.82 \pm 0.54$ & $27.78 \pm 0.37$ \\
\hline $\mathrm{MCHC}(\mathrm{g} / \mathrm{dl})$ & $36.11 \pm 0.35$ & $36.29 \pm 0.88$ & $34.72 \pm 0.33$ \\
\hline TWBC (x 109/L) & $8.5 \pm 1^{*}$ & $7.3 \pm 0.5$ & $5.4 \pm 1$ \\
\hline Platelet (x 109/L) & $115 \pm 8^{*}$ & $120 \pm 10^{*}$ & $160 \pm 15$ \\
\hline
\end{tabular}

( $(\mathrm{p}<0.05)$

HGB: Hemoglobin; HCT: Hematocrit; RBC: Red blood cell; MCV: Mean corpuscular volume; $\mathrm{MCH}$ : Mean corpuscular haemoglobin; MCHC: Mean corpuscular hemoglobin concentration; TWBC: Total white blood cell.

haematocrit $(18 \pm 0.7)$, red blood cell $(3.1 \pm 0.8)$, Mean corpuscular volume $(58.06 \pm 0.23)$ and mean corpuscular heamoglobin $(20.97 \pm$ 0.44 ) in VOC were significantly lower than the mean steady state and the controls while the total white blood cell $(8.5 \pm 1)$ concentration in VOC was significantly higher compared to the mean steady state and the controls. The mean platelet $(115 \pm 8)$ in VOC and the steady state $(120 \pm 10)$ were significantly lower when compared with the control $(160 \pm 15)$ (Table 6).

\section{Discussion}

Vessel occlusion and ischaemia caused by decrease in sickle blood cell elasticity and damage to the cell membrane are central to the pathophysiology of sickle cell anemia [25]. Pain management medications are used as remedies for vaso-occlusive pain crises. Sickle cell anaemia patients, particularly children, are vulnerable to infections leading to increased mortality [26].

The mean albumin, globulin and total protein values in VOC were significantly higher $(\mathrm{p}<0.05)$ than the mean steady state and the controls values (Table 1). Isichei [27] in his study carried out on sickle cell disease children aged 5-11 years showed that mean total protein and the mean globulin in the homozygous sicklers was very significantly greater than the values found in normal children in the same age group. The high level of globulin in sickle cell homozygous individuals both in VOC and steady states could be attributed to increased erythrocyte destruction during sickling [28]. In a study carried out in patients attending sickle cell clinic at University of Benin Teaching Hospital (UBTH) Nigeria, the mean total protein and albumin were significantly higher $(\mathrm{P}<0.05)$ in sickle cell disease patients when compared with heterozygous AS and normal controls patients [29]. Famodu, et al. [30] observed high level of albumin in sickle cell patients especially during occlusive crisis. On the contrary, Tripathi, et al. [31] found low levels of total protein and albumin in sickle cell disease individuals.

The mean haemoglobin, haematocrit, platelet and red blood cell values both in VOC and steady state were significantly lower than the controls values. The sickle cell anaemia patients are continually haemolysing their red cells with a short survival rate of the erythrocytes between 12-14 days [32] and as a result, the haemoglobin, haematocrit, platelet and red blood cells are usually lower than normal healthy individuals. This is in accordance with the result of a study carried out in the sickle cell clinic of Lagos State University Teaching Hospital, Nigeria which revealed a significant decrease $(\mathrm{p}<0.05)$ in the mean values of hemoglobin concentration in sickle cell disease patients compared with normal human subjects [33].

The total white blood cell counts in VOC and steady state were significantly higher $(\mathrm{P}<0.05)$ than in controls (Table 5$)$. This could be attributed to increase concentration of neutrophils in venous blood of sickle cell patients which include demargination of intravascular neutrophils, accelerated release from the bone marrow and reduction in the rate at which neutrophils leave the blood [34]. The platelet count in VOC and steady state were statistically significantly lower than the control (Tables 2, 5 and 6) and this is contrary to previous studies which show that platelet count is higher in sickle cell anaemia than in healthy control [35].

The MCV was significantly lower in VOC than in steady state and control and this is also in contrary with previous studies which showed higher MCV in VOC and steady state than the healthy control [36]. The result of this study showed increased levels of albumin, globulin and total protein in sickle cell disease patients in VOC and steady state but not statistically significant when compared with the apparently healthy subjects (Tables 3 and 4). This is in line with the result of a study carried out by Adu, et al. [29] who reported similar trend of albumin in sickle cell disease subjects.

\section{Conclusion}

In conclusion, this study demonstrated alterations in the biochemical and haematological parameters of sickle cell patients attending clinic at University of Nigeria Teaching Hospital, Enugu Nigeria. The study was limited with few subjects which were not enough to establish conclusive assertions on the findings.

\section{References}

1. Panepinto JA, O'Mahar KM, DeBaun MR, Loberiza FR, Scott JP (2005) Health-related quality of life in children with sickle cell disease: child and parent perception. $B r J$ Haematol 130: 437-444. [Crossref]

2. Panepinto JA (2012) Health-related quality of life in patients with hemoglobinopathies. Hematology Am Soc Hematol Educ Program 2012: 284-289. [Crossref]

3. Van Beers EJ, van Tuijn CF, Nieuwkerk PT, Friederich PW, Vranken JH, et al. (2007) Patient controlled. Analgesia versus continuous infusion of morphine during vasoocclusive crisis in sickle cell disease, a randomized controlled trial. Am J Hematol 82: 955-960.

4. Ballas SK, Smith ED (1992) Red blood cell changes during the evolution of the sickle cell painful crisis. Blood 79: 2154-2163. [Crossref]

5. Ballas SK (1995) The sickle cell painful crisis in adults: phases and objective signs. Hemoglobin 19: 323-333. [Crossref]

6. Embury SH (2004) The not-so-simple process of sickle cell vasoocclusion. Microcirculation 11: 101-113. [Crossref]

7. Frenette PS (2002) Sickle cell vaso-occlusion: multistep and multicellular paradigm. Curr Opin Hematol 9: 101-106. [Crossref]

8. Eaton WA, Hofrichter J (1987) Hemoglobin S gelation and sickle cell disease. Blood 70: $1245-1266$. [Crossref] 
9. Mozzarelli A, Hofrichter J, Eaton WA (1987) Delay time of hemoglobin S polymerization prevents most cells from sickling in vivo. Science 237: 500-506. [Crossref]

10. Eaton WA, Hofrichter J, Ross PD (1976) Delay time of gelation: A possible determinant of clinical severity in sickle cell disease. Blood 47: 621-627.

11. Turhan A, Weiss LA, Mohandas N, Coller BS, Frenette PS (2002) Primary role for adherent leukocytes in sickle cell vascular occlusion: a new paradigm. Proc Natl Acad Sci U S A 99: 3047-3051. [Crossref]

12. Turhan A, Jenab P, Bruhns P, Ravetch JV, Coller BS, et al. (2004) Intravenous immune globulin prevents venular vaso-occlusion in sickle cell mice by inhibiting leukocyte adhesion and the interactions between sickle erythrocytes and adherent leukocytes. Blood 103: 2397-2400.

13. Anyaegbu CC, Okpala IE, Akren'Ova YA, Salimonu LS (1998) Peripheral blood neutrophil count and candidacidal activity correlate with the clinical severity of sickle cell anaemia (SCA). Eur J Haematol 60: 267-268.

14. Ohene-Frempong K, Weiner SJ, Sleeper LA, Miller ST, Embury S, et al. (1998) Cerebrovascular accidents in sickle cell disease: rates and risk factors. Blood 91: 288294.

15. Castro O, Brambilla DJ, Thorington B, Reindorf CA, Scott RB, et al. (1994) The acute chest syndrome in sickle cell disease: incidence and risk factors. The Cooperative Study of Sickle Cell Disease. Blood 84: 643-649. [Crossref]

16. Platt OS, Brambilla DJ, Rosse WF, Milner PF, Castro O, et al. (1994) Mortality in sickle cell disease. Life expectancy and risk factors for early death. $N$ Engl J Med 330: 1639-1644. [Crossref]

17. Fadlon E, Vordermeier S, Pearson TC, MireSluis AR, Dumonde DC, et al. (1998) Blood polymorphonuclear leukocytes from the majority of sickle cell patients in the crisis phase of the disease show enhanced adhesion to vascular endothelium and increased expression of CD64. Blood 91: 266-274.

18. Lard LR, Mul FP, de Haas M, Roos D, Duits AJ (1999) Neutrophil activation in sickle cell disease. J Leukoc Biol 66: 411-415. [Crossref]

19. Okpala I, Daniel Y, Haynes R, Odoemene D, Goldman J (2002) Relationship between the clinical manifestations of sickle cell disease and the expression of adhesion molecules on white blood cells. Eur J Haematol 69: 135-144.

20. Hofstra TC, Kalra VK, Meiselman HJ, Coates TD (1996) Sickle erythrocytes adhere to polymorphonuclear neutrophils and activate the neutrophil respiratory burst. Blood 87: 4440-4447.
21. Hanson MS, Wandersee NJ, Hessner M, Pritchard KA, Hogg N, et al. (2013) Neutrophil activation in sickle cell disease: biochemical and functional changes at baseline and during acute vaso-occlusive crises. Blood 122: 992.

22. Lum AF, Wun T, Staunton D, Simon SI (2004) Inflammatory potential of neutrophils detected in sickle cell disease. Am J Hematol 76: 126-133. [Crossref]

23. Finnegan EM, Turhan A, Golan DE, Barabino GA (2007) Adherent leukocytes capture sickle erythrocytes in an in vitro flow model of vaso-occlusion. Am J Hematol 82: 266-275.

24. Dacie JV, Lewis SM (2006) Practical Hematology (10th edition) Lewis, Bain and Bates, Churchill Livingstone, An Imprint of Elsevier, 25-57.

25. Maakaron JE (2015) Sickle Cell Anemia. Medscape 6: 7-15.

26. Falcão RP, Donadi EA (1989) Infection and immunity in sickle cell disease. $A M B$ Rev Assoc Med Bras 35: 70-74. [Crossref]

27. Isichef UP (1979) Serum protein profile in sickle cell disease. Journal of Clinical Pathology 32: 117-121.

28. Adenike FA, Bakare AR, Fajimi JL, Ogunyemi EO, Obisesan KA, et al. (1998) Serum protein levels in sickle cell disease. Afr J Med \& Pharm Sci 1: 40-43.

29. Adu EM, Okosun RE, Bini EN, Ophori EA (2012) Effects of the sickle cell (s) gene on serum protein profile. C J Bi oMed 6: 1-5.

30. Famodu AA, Omodiale P, Adedeji MO, Reid HL (1987) Serum protein study in adult Nigerians with sickle cell anaemia. Med Sci Res 15: 193-194.

31. Tripathi S, Dadsena R, Kumar A (2011) Study of Certain Biochemical Parameters in Patients of Sickle Cell Anemia Adv Biores 2: 79-81.

32. Osaghae DO (1987) The diagnostic value of leucocyte counts in sickle cell anaemia. Dissertation for West African Postgraduate Medical College, Lagos 1-76.

33. Akinbami A, Dosunmu A, Adediran A, Oshinaike O, Adebola P, et al. (2012) Haematological values in homozygous sickle cell disease in steady state and haemoglobin phenotypes AA controls in Lagos, Nigeria. BMC Research Notes 5: 396.

34. Konotey-Ahulu FID (1992) The sickle cell disease patient. Macmillan, Hong Kong, 341-348.

35. Jaffe DM, Fleisher GR (1991) Temperature and total white blood cell count as indicators of bacteremia. Pediatrics 87: 670-674. [Crossref]

36. Omoti EC (2005) Haematological values in sickle cell anaemia in steady state and during vaso-occlusive crisis in Benin city, Nigeria. Annals of African Medicine 4: 62-67.

Copyright: (C2019 Onyekwelu KC. This is an open-access article distributed under the terms of the Creative Commons Attribution License, which permits unrestricted use, distribution, and reproduction in any medium, provided the original author and source are credited. 